\title{
THE NEW DAWN - COMMERCIAL AND REgULATORY CONSIDERATIONS AFFECTING LIQUIFIED NATURAL GAS EXPORT FROM BRITISH COLUMBIA
}

\author{
DAVID Holub, LAURA LETOURNEAU, \\ JANICE BUCKINGHAM, AND GORD NETTLETON ${ }^{* *}$
}

This article explores a sampling of commercial and regulatory issues, challenges, and risks encountered in the development of the Kitimat Liquified Natural Gas $(L N G)$ project. The authors describe practical and innovative solutions proposed by lawyers to address the issues, resolve the challenges, and mitigate the risks of an LNG export project. The commercial and regulatory arrangements of the Kitimat LNG project are described. Industrial development on Aboriginal lands is overviewed, particularly in regards to the need for consultation with Aboriginal communities and First Nations groups affected by the proposed LNG project. The National Energy Board export authorizations are also overviewed, with a focus on the export licence requirement for an LNG project.
Cet article explore un échantillon de questions, de problèmes et de risques commerciaux et réglementaires survenus dans le courant du projet Kitimat Liquified Natural Gas (GNL). L'auteur décrit les solutions pratiques et novatrices proposées par les avocats pour aborder les questions, régler les problèmes et réduire les risques associés à un tel projet d'exportation. Les arrangements commerciaux et réglementaires du projet de GNL Kitimat y sont décrits. L'activité industrielle sur les terres autochtones est encadrée, tout particulièrement vu le besoin de consultation des communautés autochtones et des groupes des Premières nations concernés. Les autorisations d'exportation de l'Office national de l'énergie sont également encadrées avec une attention spéciale aux exigences relatives aux permis d'exportation d'un projet de GNL.

\section{TABLE OF CONTENTS}

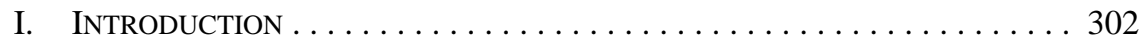

II. The Kitimat LNG PRoJect $\ldots \ldots \ldots \ldots \ldots \ldots \ldots \ldots \ldots \ldots \ldots \ldots \ldots \ldots$

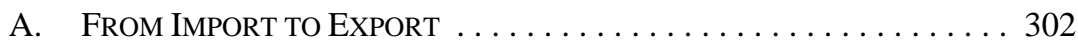

B. Description of the Project . . . . . . . . . . . . . . . . . . 303

C. Project Participants $\ldots \ldots \ldots \ldots \ldots \ldots \ldots \ldots \ldots \ldots \ldots \ldots$

III. OVERVIEW OF PRIMARY COMMERCIAL

AND REgUlatory ARRANGEMENTS $\ldots \ldots \ldots \ldots \ldots \ldots \ldots \ldots \ldots$

IV. INDUSTRIAL DEVELOPMENT ON ABORIGINAL RESERVE

AND TRADITIONAL LANDS $\ldots \ldots \ldots \ldots \ldots \ldots \ldots \ldots \ldots \ldots \ldots \ldots \ldots \ldots \ldots$

A. JURISDICTIONAL CONSIDERATIONS $\ldots \ldots \ldots \ldots \ldots \ldots \ldots \ldots \ldots \ldots$

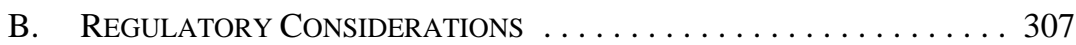

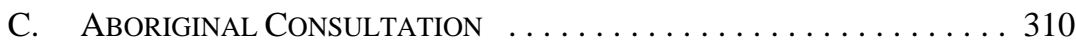

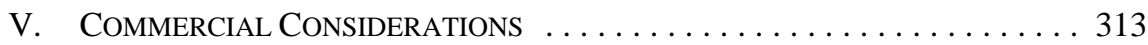

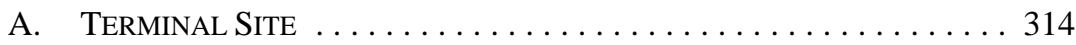

B. Pacific Trail Pipelines Considerations $\ldots \ldots \ldots \ldots \ldots \ldots 318$

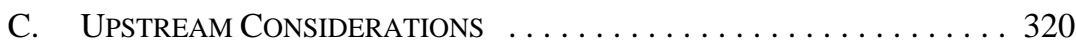

VI. NEB EXPORT AUTHORIZATIONS $\ldots \ldots \ldots \ldots \ldots \ldots \ldots \ldots \ldots \ldots \ldots \ldots \ldots \ldots$

A. BACKGROUND TO THE EXPORT LICENCE REQUIREMENT . . . . . . . 323

* $\quad$ Apache Canada Ltd.

Osler, Hoskin \& Harcourt, LLP. Special thanks to Sander Duncanson, Ron Franklin, and Laurie Hildebrand, associates at Osler, Hoskin \& Harcourt, LLP, for their contributions to the research and writing of this article. 
B. THE PARADIGM SHIFT:

EXPORT LICENCES AND LNG PROJECTS . . . . . . . . . . . . . . . . 326

C. IS MORE INNOVATION IN EXPORT LICENCE

REQUIREMENTS STILL REQUIRED? . . . . . . . . . . . . . 332

VII. MARKETING ARRANGEMENTS AND ROLE OF LNG BuYERS . . . . . . . . . . 334

VIII. MANAGING RisKS ACROSS THE PROJECT PRIOR

TO MAKING A FinAL INVESTMENT DECISION . . . . . . . . . . . . . . . . 334

\section{INTRODUCTION}

Canada is experiencing a "new dawn" in its energy industry. With the significant discoveries of shale gas in North America, the dynamics of the Canadian gas market have shifted dramatically. The resultant oversupply of gas has coincided with a marked increase in energy demand from the Pacific Rim and created an opportunity for Canada to expand its horizons into exporting liquefied natural gas (LNG).

Any new and developing industry brings with it certain commercial, political, and legal challenges which require visionary thinking and innovative solutions. Lawyers can play a large role in the advancement of such industries, as they provide creative, solution-oriented thinking that assists in the development of strategies necessary to meet the challenges and mitigate the risks that are ultimately faced.

This article explores a sampling of the many commercial and regulatory issues and challenges that have been encountered to date in the development of the Kitimat LNG project, and the inventive and practical legal solutions that have resolved them. As will become evident, turning the concept of an LNG export facility in northwest British Columbia into a real project requires a significant dedication of time, capital, resources, and innovation, as strategies and long-term arrangements being developed need to be agile enough to respond to ever evolving market players and conditions.

\section{The Kitimat LNG PRoJect}

\section{A. FROM IMPORT TO EXPORT}

Prior to the significant discoveries of shale gas in northeast British Columbia, there were some who thought LNG import and regasification would be required on the west coast to fuel expanding oil sands development. A site with marine access was identified, environmental permits were obtained, and a positive commercial relationship was established with the Haisla First Nation (Haisla Nation) for an LNG import and regasification project. Not long after, coincident to the time China and India's demand for LNG increased, development of the Horn River Marcellus and Barnet shales occurred. The resultant overabundance of North American gas supply, combined with increased LNG market demands, made it abundantly clear that a natural gas liquefaction plant for the export of LNG would be a much more economical use of the site than one directed at importing LNG for regasification. The idea for a new Canadian energy export project was launched. 


\section{B. Description of the Project}

Kitimat LNG is a project to construct and operate an LNG plant to liquefy natural gas produced in western Canada for export to markets in the Asia Pacific region. The Kitimat LNG facility will be located at Bish Cove, near the Port of Kitimat, British Columbia. It will receive natural gas from the North American grid, largely supplied by natural gas reserves in northeast British Columbia (via the Pacific Trail Pipelines), provide for liquefaction, LNG storage and send-out, as well as marine offloading (collectively, these functions comprise the Kitimat LNG Project).

The Pacific Trail Pipelines (PTP) is a permitted, but as yet unconstructed, 463 kilometre pipeline intended to transport natural gas from Summit Lake to Kitimat. It is integral to the Kitimat LNG Project and is owned by the Kitimat LNG Project proponents.

\section{Project Participants}

Apache Canada Ltd. (Apache) became the first Canadian gas producer willing to invest in Canadian LNG export infrastructure and position itself to find new markets for, and monetize, its substantial gas supply. ${ }^{1}$ In January 2010, KM LNG Operating General Partnership (KM LNG), a wholly owned subsidiary of Apache, purchased a 51 percent interest in the Kitimat LNG Project from Galveston LNG Inc. (Galveston).

EOG Resources Canada Inc. (EOG) and Encana Corporation (Encana), which hold similar land positions in the Horn River Basin, shared the vision and soon joined the Kitimat LNG Project. In May 2010, a wholly-owned subsidiary of EOG agreed to acquire Galveston's remaining 49 percent interest in the Kitimat LNG Project. On 15 March 2011, KM LNG, EOG, and Encana entered into certain arrangements that resulted in a wholly-owned subsidiary of Encana purchasing a 30 percent interest in the Kitimat LNG Project. EOG retained a 30 percent interest and KM LNG retained a 40 percent interest in the Kitimat LNG Project, as well as operatorship (KM LNG, EOG, and Encana are collectively referred to as the Joint Owners). ${ }^{2}$

Through a similar series of transactions, some of which are described in greater detail in this article, Apache, EOG, and Encana acquired corresponding interests in the PTP.

\section{OVERVIEW OF PRIMARY COMMERCIAL AND REgUlatory ARRANGEMENTS}

To date, the proponents of the Kitimat LNG Project have secured a number of the critical cornerstones to achieving a viable project, including:

(1) An interim regulatory agreement with the federal Crown, British Columbia Oil and Gas Commission (OGC), and Haisla Nation providing for the regulation of the

The original proponent of the Kitimat LNG Project (a non-producer) initially contemplated and designed the project as an LNG import facility.

“Ownership,” online: Kitimat LNG <http://www.kitimatlngfacility.com/Project/project_ownership. aspx>. 
operator's activities in respect of the proposed LNG facilities as if the facilities were located on provincial Crown land, pending the coming into force of regulations under the First Nations Commercial and Industrial Development Act ${ }^{3}$ (the Interim Regulatory Agreement);

(2) Various environmental permits and authorizations relating to the site of the proposed Kitimat LNG Project;

(3) A benefits agreement with the Haisla Nation relating to the development of the proposed LNG facilities on their lands (the Haisla Benefits Agreement);

(4) A commercial lease with Aboriginal Affairs and Northern Development Canada (AANDC) on behalf of the Haisla Nation, governing the site of the proposed LNG facility (the Commercial Lease);

(5) A foreshore lease with the Province of British Columbia, governing marine access to the site of the proposed LNG facilities (the Foreshore Lease);

(6) A joint operating agreement for the proposed LNG facilities under which KM LNG was appointed as operator (the Kitimat JOA);

(7) A limited partnership and shareholder agreement governing the ownership and operation of the Pacific Trail Pipelines Limited Partnership and its general partner;

(8) A benefits agreement with the First Nations (PTP) Group Limited Partnership (FNLP) relating to the development of the proposed PTP on the traditional lands of 16 First Nations (the PTP Benefits Agreement);

(9) A National Energy Board export licence for the long-term export of LNG (the Licence); and

(10) A coordinated marketing agreement under which the proponents are negotiating the required LNG sale and purchase agreements. ${ }^{4}$

\section{INDUSTRIAL DEVELOPMENT ON ABORIGINAL RESERVE AND TRADITIONAL LANDS}

\section{A. JURISDiCTIONAL CONSIDERATIONS}

Developing a substantive new energy project presented numerous jurisdictional issues arising from overlapping federal and provincial authorities and regulatory processes. The lands upon which the Kitimat LNG Project are to be situated include: (1) the Haisla Nation Aboriginal Reserve lands; (2) foreshore lands owned by the Crown but that also fall within 
Haisla Nation traditional lands; and (3) rights of way for the PTP crossing Crown and privately held lands over which 16 First Nations assert Aboriginal rights.

On the Haisla Nation Aboriginal Reserve lands, tenure for the Kitimat LNG facilities is secured through the Commercial Lease. In the scope of negotiating and drafting the Commercial Lease, the federal government was concerned about the nature, development, operation, and decommissioning of the LNG facility and its impact on the leased premises. Although they could address some of their issues by embedding standard commercial landlord provisions into the Commercial Lease, there remained gaps. While AANDC was legislatively authorized to lease the lands, there was no federal agency willing to actively regulate the industrial activity to be conducted upon such lands. Correspondingly, no provincial regulatory enactments applied to operations on reserve lands, as section 91(24) of the Constitution Act, $1867^{5}$ deems "Indians, and Lands reserved for the Indians" as an exclusive head of federal jurisdiction. If a federal regulatory regime existed that mirrored the provincial regulatory regime for the construction of the Kitimat LNG facility, the Joint Owners would have simply proceeded under the applicable federal regulations. The absence of such federal regulations was problematic because it created considerable uncertainty over what rules would govern the construction and operation of such a major industrial project on the Haisla Nation lands.

To address this uncertainty, the Joint Owners turned to the 2005 FNCIDA. ${ }^{6}$ That Act recognizes that effective regulatory regimes are required to govern industrial undertakings on First Nations lands, but that federal legislation, as it existed in 2005, did not provide sufficient authority for the federal government to establish such regimes. ${ }^{7}$ Accordingly, the FNCIDA provides a mechanism where the federal government, at the request of a First Nation, may make regulations to govern commercial and industrial undertakings on that First Nation's reserve lands. ${ }^{8}$ These regulations may impose laws of the province on reserve lands. If the regulation under the FNCIDA deems provincial laws to apply to the undertaking on reserve lands, a tripartite agreement is typically entered into among the federal government, the provincial government, and the First Nation whereby the provincial government agrees to apply its laws to undertakings on the reserve lands and the costs of enforcing such provincial laws are allocated between the parties.

Creating a new regulation under the FNCIDA involves extensive and lengthy negotiations between the federal and provincial governments, the affected First Nations, and the project proponents. Although there had been two prior FNCIDA processes initiated, they primarily involved identifying a discrete set of provincial regulations and formally applying them to the affected First Nations lands. In the case of the Kitimat LNG facility, the negotiating parties had to anticipate all possible provincial acts and regulations that would apply to a mega industrial project whose detailed engineering and design had not been fully completed. This was further complicated by the fact that the potentially applicable provincial regulatory authority may default to other third parties (for example, districts, municipalities, or the

(UK) 30 \& 31 Vict, c 3, reprinted in RSC 1985, App II, No 5.

Supra note 3. This Act came into force 1 April 2006 and there are currently only two regulations promulgated under it.

Ibid, Preamble.

Ibid, s 5(1). 
affected First Nation itself) which may not be equipped or prepared to perform such functions and assume the associated responsibilities (for example, fire services). Consequently, such provincial regulatory functions can become the subject of yet further negotiations for individual service agreements to explicitly confirm the roles and obligations of the relevant parties.

Given the complex, time-consuming nature of this process, the federal government could not guarantee that it could establish the necessary regulation within a timeline that would coincide with the Kitimat LNG Project requirements. In the context of a major capital investment, such regulatory uncertainty led to an unacceptable level of commercial risk to each of the proponents, AANDC, and the Haisla Nation. It was, therefore, necessary to develop an innovative solution.

The legal working group settled on a contractual solution that sought to create the legal certainty that was lacking in the period before the FNCIDA regulations were proclaimed. The Interim Regulatory Agreement represents Canada's first such agreement. In it, the OGC was authorized to regulate the activities of KM LNG in respect of the facility as if it were located on provincial Crown lands.

The primary challenge for the parties was to consider how to create a regulatory regime within a contractual framework recognizing that the remedy, enforcement, and appeal mechanisms inherent in a legislative context could not be seamlessly adopted into contract. This trail-blazing exercise required the legal working group to revert to first principals to close the gap between the legislative and contractual regimes. There were many discussions of basic constitutional law, as well as debates over how best to adapt statutory solutions to contract while balancing the interests of the various parties.

For example, the remedies and enforcement tools available to the OGC under the British Columbia Oil and Gas Activities Act ${ }^{9}$ derive from the Crown, as does the avenue for appeal by the operator. Absent making the British Columbia provincial Crown and the British Columbia Court of Appeal parties to the Interim Regulatory Agreement (which carried its own layers of political and jurisdictional complications), there remained a gap. While the grant of jurisdiction from the federal government to the provincial government can be achieved by an acknowledgement from all of the parties, in this case the jurisdiction shifted from the federal government to the OGC. Understandably, the OGC was not prepared to oversee the regulation of the Kitimat LNG facility outside of its prescribed jurisdiction without having proper safeguards in place. Safeguards that needed to be considered included, among others, indemnities and immunities from lawsuit. As a result of a creative and collaborative effort, a precedent now exists for managing such a jurisdictional challenge. 


\section{B. REgUlatory CONSIDERATIONS}

Large LNG industrial projects require both federal and provincial regulatory authorizations and environmental assessment approvals. ${ }^{10}$ Applications for these regulatory authorizations must occur simultaneously with Aboriginal consultation and project planning. Understanding the process and timelines of, and planning for, these regulatory and consultation requirements will greatly minimize the potential for project delays.

At the provincial level in British Columbia, project proponents typically require authorizations from: (1) the OGC to construct and operate any LNG terminal or pipeline; (2) the Ministry of Forests, Lands and Natural Resource Operations for surface rights on Crown lands (including the foreshore) and for authorizations in relation to heritage resources; and, (3) the Ministry of Environment, authorizing any air or water emissions and for any longterm water withdrawals. Depending on the specific project proposal, additional provincial authorizations may be required as well. In the case of PTP, for example, a Park Use Permit administered by BC Parks (working closely with the OGC) for pipeline and road construction requirements through the Burnie River Protected Area was also required. Federally, LNG export projects and pipeline projects may require approvals from Transport Canada under the Navigable Waters Protection Act ${ }^{11}$ to construct any work in, across, over, or under navigable water; from Fisheries and Oceans Canada (DFO) under the Fisheries Act ${ }^{12}$ to commit harmful alteration, disruption, or destruction of fish habitat; from Environment Canada under the Canadian Environmental Protection Act, $1999^{13}$ to dispose of dredged material at sea; and, if the project is to be located on reserve lands, from AANDC under the Indian Act ${ }^{14}$ to construct and operate a project on a First Nations reserve. All LNG export projects will also require export authorization from the NEB, which is discussed in detail in this article. Each provincial and federal regulator follows different processes and imposes separate requirements prior to granting an authorization.

In addition to these various provincial and federal authorizations, oil and gas activities in British Columbia may require an environmental assessment under either or both of the British Columbia Environmental Assessment Act ${ }^{15}$ and the federal Canadian Environmental Assessment Act. ${ }^{16}$ The Canada-British Columbia Agreement for Environmental Assessment Cooperation (2004) $)^{17}$ provides for coordinated environmental assessment processes to avoid

We note that subsequent to the time that this article was presented at the Canadian Energy Law Foundation - 2012 Jasper Research Seminar, significant changes have been made to the federal legislative scheme applicable to LNG exports. These changes are seen in the Jobs, Growth and Longterm Prosperity Act, SC 2012, c 19, which received royal assent on 29 June 2012. The legislation contains amendments to the National Energy Board Act, RSC 1985, c N-7 [NEB Act], which affect the review of oil and gas export and gas import applications by the National Energy Board (NEB). The full extent of these changes is now being explored by the NEB through an industry consultation process as directed in a letter from the NEB dated 20 September 2012 (Letter from Sheri Young, Secretary to the NEB, to All Interested Parties (20 September 2012), online: NEB <http://www.neb-one.gc.ca/clfnsi/rpblctn/ctsndrgltn/rrggnmgpnb/xprtsndmprt/nb2012_09_20-eng.pdf >).

RSC 1985, c N-22, s 5.

RSC 1985, c F-14, s 35(2).

SC 1999, c 33, s 127.

RSC 1985, c I-5, ss 18(2), 28(2), 58(4)(b).

SBC 2002, с 43 [BCEAA].

SC 1992, c 37, as repealed by Jobs, Growth and Long-term Prosperity Act, supra note 10 [CEAA]. Signed 11 March 2004, online: Canadian Environmental Assessment Agency <http://www.ceaa.gc.ca/ default.asp?lang=En\&n=04A20DBC-1>. 
uncertainty and duplication between the provincial and federal environmental assessment processes and to facilitate a "one project, one review" approach when both processes are triggered. Therefore, if environmental assessments are required under both the BCEAA and the $C E A A$, project proponents should encourage coordination between the provincial and federal governments to ensure a single environmental assessment is carried out.

Under the $B C E A A$, if a proposed activity constitutes a "reviewable project" pursuant to the Reviewable Projects Regulation, ${ }^{18}$ then an environmental assessment will be required. Examples of oil and gas projects that require environmental assessments are:

(1) Any natural gas processing facility with a capacity to process over $200 \mathrm{MMscf} / \mathrm{d}$ (5.634 million $\mathrm{m}^{3} / \mathrm{d}$ ) or that will result in more than 2 tonnes/day of sulphur emissions;

(2) Any pipeline that: (a) has a diameter of less than 4.5 inches $(114.3 \mathrm{~mm})$ and that is longer than $60 \mathrm{~km}$; (b) has a diameter of between 4.5 inches $(114.3 \mathrm{~mm})$ and 12 inches (323.9 mm) and that is longer than $50 \mathrm{~km}$; or, (c) is larger than 12 inches (323.9 mm) in diameter and that is longer than $40 \mathrm{~km}$; and

(3) Any offshore oil or gas facility. ${ }^{19}$

The British Columbia Minister of the Environment may also require an environmental assessment where one is not automatically required if the Minister believes that the proposed project may have a significant adverse environmental, economic, social, heritage, or health effect, and that requiring an environmental assessment is in the public interest. ${ }^{20}$

The Executive Director of the British Columbia Environmental Assessment Office (EAO) determines the scope of each environmental assessment, including whether that assessment should consider cumulative effects and what persons and organizations should be consulted during the environmental assessment. ${ }^{21}$ Once the environmental assessment is complete, the EAO must refer the project to the Minister of Environment and a designated member of Cabinet to issue an environmental assessment certificate. In considering whether to grant the certificate, these ministers may take into consideration any matter they consider relevant to the public interest. ${ }^{22}$

In addition to provincial environmental assessment requirements, environmental assessments under the CEAA are required wherever: (1) a project is proposed on federal land; (2) a project will receive federal funding; (3) the federal government is the proponent of a proposed project; or (4) where a federal authorization is required under any of the provisions

BC Reg 370/2002.

Ibid, s 10, Table 8.

BCEAA, supra note 15 , s $6(1)(a)$.

Ibid, s 11.

Ibid, s 17. 
listed in the Law List Regulations, ${ }^{23}$ which includes the above authorizations from Transport Canada, DFO, Environment Canada, and AANDC. ${ }^{24}$

Federal environmental assessments may consist of a screening level report, a comprehensive study, or an assessment by a mediator or review panel, depending on whether the proposed project is listed in the Comprehensive Study List Regulations ${ }^{25}$ and whether the responsible authority determines either that the proposed project may cause significant adverse environmental effects or that public concerns warrant a reference to a mediator or review panel. ${ }^{26}$ The CSLR requires that a comprehensive study level of assessment at a minimum is carried out for any "facility for the liquefaction, storage or regasification of liquified natural gas, with a liquefied natural gas processing capacity of more than $3000 \mathrm{t} / \mathrm{d}$ or a liquefied natural gas storage capacity of more than $50000 \mathrm{t}$ "27 or for "an oil and gas pipeline more than $75 \mathrm{~km}$ in length on a new right of way." ${ }^{28}$ Once the environmental assessment is complete, the responsible authority may proceed to issue the necessary approval (or otherwise proceed with the project) if they determine that the project is not likely to result in any significant adverse environmental effects, taking into account mitigation measures or that any significant adverse environmental effects can be justified in the circumstances.

Finally, while not legally required, LNG project proponents typically submit to a Technical Review Process of Marine Terminal Systems and Transhipment Sites, or “TERMPOL,” review process, administered by Transport Canada. ${ }^{29}$ TERMPOL reviews apply to marine shipments of oil, natural gas (including LNG), and certain chemicals in Canadian territorial waters. The review focuses on the proposed shipping route through Canadian waters, navigation controls, the proposed marine terminal or transshipment site, and the proposed vessels to be used. The intent of TERMPOL reviews is "to ameliorate, where possible, those elements of a proposal which could, in certain circumstances, threaten the integrity of the ship's hull and its cargo containment system and, consequently, the environment in the vicinity of the design ship while it is navigating in waters under Canadian jurisdiction.”30 TERMPOL reviews also consider the potential effects of increased shipping activity on existing regional shipping networks and fishing ground activities, perceived risks to communities along the shipping route, and the navigational safety of the shipping proposal. If a proponent submits to the TERMPOL process, it may be able to rely upon that process to exclude certain aspects of the LNG shipping proposal from other regulatory reviews, including environmental assessments. ${ }^{31}$

As an LNG project progresses, there may be modifications or optimizations to design that occur that necessitate an amendment to certain approvals. Any changes to existing approvals

SOR/94-636, Schedule I.

CEAA, supra note 16, ss 5(1)(b)-(d). Export approvals from the NEB do not trigger the need for a CEAA assessment.

SOR/94-638 [CSLR].

CEAA, supra note 16 , ss $14,20(1)$.

CSLR, supra note 25, Schedule, s 13(d).

Ibid, Schedule, s 14(a).

See Transport Canada, TERMPOL Review Process 2001, TP 743E (Ottawa: Transport Canada, 2001), online: Transport Canada <http://www.tc.gc.ca/publications/EN/TP743/PDF/HR/TP743E.pdf>.

Ibid at para 1.1.3.

Ibid at para 1.2.3. 
need to be understood and proponents need to be aware that such amendments may trigger their own processes and timelines. In any event, decisions, approvals, or permits by a Crown agency will trigger a duty to consult, which must be taken into account as an important project element from the outset.

\section{Aboriginal Consultation}

A critical consideration when doing business on Aboriginal reserve or traditional lands is Aboriginal consultation. If improperly managed by the Crown (that is, governments and government agencies), Aboriginal consultation issues can lead to project approvals being successfully challenged, years of litigation for project proponents, and overall uncertainty for a project. Consequently, there is large incentive on the project proponent to work collaboratively with the Crown to engage First Nations. Before outlining ways in which project proponents can mitigate these risks, it is important to briefly outline the nature and scope of the duty to consult. ${ }^{32}$

\section{BACKGROUND ON THE DUTY TO CONSUlT}

Section 35 of the Constitution Act, $1982^{33}$ provides that "[t]he existing aboriginal and treaty rights of the aboriginal peoples of Canada are hereby recognized and affirmed." 34 Aboriginal rights and treaty rights are not absolute, however, and may be infringed, if justified. Thus, where an Aboriginal community can establish that it has or is likely to have Aboriginal or treaty rights in an area affected by a particular project, the Crown will be required to demonstrate that any infringement resulting from the project is justified. In addition, whenever a government action or approval has the potential to affect the rights or interests of an Aboriginal community, the Crown owes that community a duty to consult and possibly accommodate.

In the leading case on the duty to consult, Haida Nation v. British Columbia (Minister of Forests), ${ }^{35}$ the Supreme Court of Canada emphasized that the scope of the government's consultation obligation is proportionate to the strength of the asserted right or title, and the seriousness of the impact of the proposed decision. As a result, the scope of the duty to consult will differ with the circumstances under consideration. In cases where "the claim to title is weak, the Aboriginal right limited, or the potential infringement minor," the only duty on the Crown may be to "give notice, disclose information, and discuss any issues raised in response to the notice." 36 However, in cases where "a strong prima facie case for the claim is established, the right and potential infringement is of high significance to the Aboriginal peoples, and the risk of non-compensable damage is high ... deep consultation” 37 may be

It is beyond the scope of this article to provide a thorough analysis of the current state of aboriginal law in Canada. Instead, this article is restricted to the issues that project proponents must overcome in planning and executing a new LNG export project in Canada. Being Schedule B to the Canada Act 1982 (UK), 1982, c 11.

"Aboriginal peoples" includes "the Indian, Inuit, and Métis peoples of Canada": ibid, s 35(2). The term "First Nation" is generally used to refer to an Indian band under the Indian Act.

2004 SCC 73, [2004] 3 SCR 511 at para 39 [Haida].

Ibid at para 43.

Ibid at para 44. 
required. While the precise requirements will vary with the circumstances, the Supreme Court concluded that the consultation at such stage may require the Crown to:

(1) Provide those claiming the Aboriginal or treaty right with an opportunity to make submissions for consideration;

(2) Permit those claiming a right to formally participate in the decision-making process; and

(3) Provide written reasons to "show that Aboriginal concerns were considered and to reveal the impact they had on the decision."38

In cases between those two ends of the spectrum, the Crown will be required to assess the appropriate level of consultation necessary under the circumstances.

It is important to recognize that the duty to consult is not about ensuring Aboriginal approval is obtained for a project. The duty to consult is the Crown's duty to inform Aboriginals about activities that may impact their rights and provide them with opportunities to discuss how the project may impact those rights and to give input on project design. Furthermore, the Supreme Court of Canada has held that Aboriginal groups have a corresponding obligation to act reasonably and participate in the consultation process. ${ }^{39}$

\section{PROPONENT’S Role In Mitigating ABORIGINAL RisKS}

In Haida, the Supreme Court of Canada made it clear that the duty to consult is owed by the Crown and not third parties. However, the Court recognized that governments can delegate procedural aspects of the consultation obligation to third parties. ${ }^{40}$ As a result, most governments in Canada expect project proponents to carry out the majority of consultation activities themselves and have the Crown determine whether the duty to consult is satisfied prior to issuing the approval in question. This approach essentially places the onus on the project proponent to carry out Aboriginal consultation.

In British Columbia, however, several agencies retain the procedural aspects of the duty to consult. For example, the OGC has published consultation guidelines for several First Nations, including those First Nations that are signatories to Treaty $8 .^{41}$ These guidelines place the onus for First Nations consultation on the OGC, not the project proponent, but stress that project proponents play an important role in the consultation process. The Draft Procedure states:

The engagement of proponents with potentially affected First Nations can facilitate effective and timely information exchange, modify plans to mitigate and avoid impacts to Aboriginal interests, and can also

Ibid.

See e.g. ibid at para 42.

Ibid at para 53.

OGC, Draft Interim Consultation Procedure with Treaty 8 First Nations (Victoria: OGC, 2011), online:

OGC <http://www.bcogc.ca/ document.aspx?documentID=1074\&type=.pdf $>$ [Draft Procedure]. 
contribute to some of the Province's and Commission's broader objectives, including partnerships and relationship building with First Nations. ${ }^{42}$

These guidelines also suggest that the project proponent may be involved in developing agreements with an affected First Nation as a form of accommodation. ${ }^{43}$

There are several steps that project proponents in British Columbia can take to mitigate the risk of project delays caused by inadequate Crown consultation or unjustified infringement. First, proponents should identify whether there are any Aboriginal rights or treaty rights in areas that may be impacted by the project in question. In addition, a proponent needs to understand what government approvals will be required from which Crown agency so that the proponent can work with the applicable government authority to discuss the consultation process, confirm their respective roles, and follow through in a timely fashion. While a certain degree of reliance on the applicable government agency may be appropriate, proponents should recognize that any deficiency in consultation by the agency may create significant timing and commercial risks for the project. Therefore, it is advisable for a proponent to ensure that all potentially affected Aboriginal groups are adequately informed about the proposed project and are provided with opportunities to express concerns and/or provide input into the planning process. Finally, proponents may mitigate Aboriginal risk through entering into commercial agreements with potentially affected Aboriginal communities.

It is important to recognize that absent an express statutory requirement to negotiate a commercial agreement with an Aboriginal community, a consultation obligation does not necessarily give rise to an obligation to enter into an agreement. ${ }^{44}$ However, an agreement is a tool that can be used to mitigate a potential impact on treaty or Aboriginal rights or title and to mitigate the environmental or socio-economic impacts from a project. Agreements can be incorporated into the relationship-building process to set the framework for a strong and successful partnership, can provide the foundation for a new (or improve an existing) relationship, and over time can provide further opportunities for the project proponent and the Aboriginal group to work together to achieve shared goals. A range of types of agreements that reflect the level of consultation that is required and appropriate for a particular group should be considered. Forms of such agreements can range from a basic memorandum of understanding that governs relations during a short exploration phase to a full-blown IBA that covers the socio-economic and environmental issues for the life of a major project. What follows is an explanation of some common forms of agreements.

Ibid at 12 .

Ibid at 10 .

In Nunavut, for example, a major project cannot proceed until the proponent has entered into an impact and benefits agreement (IBA) with the pertinent Inuit organization. If an IBA cannot be agreed upon, there is an established arbitration process. In addition, Aboriginal groups and their legal counsel are now often more sophisticated than they have been historically. They have correctly identified that although they are owed consultation and perhaps even accommodation by the Crown, they are more likely to obtain financial benefits from project proponents. This is because it is the project proponents who are most significantly impacted if a proposed project is delayed or not approved. Such knowledge, combined with the legal developments of the past decade, result in Aboriginal groups having significant leverage over project proponents in the regulatory approval process. 


\section{a. Memoranda of Understanding or Consultation Protocols}

Generally, these are non-binding agreements that describe the consultation process and the intention of the parties to work together to explore opportunities. These are commonly used for exploratory programs in oil and gas or mining, have short durations, and generally describe a process to explore business or employment opportunities. However, they also may be appropriate for an Aboriginal group that falls on the low end of the consultation spectrum.

\section{b. Environmental and Socio-Economic Agreements}

These agreements are often used to define the process for communicating and sharing information regarding the impacts from a project and the mitigation measures committed to by the project proponent. They may address frequency of meetings, appointment of representatives, capacity funding, issues that will be discussed, and a process for resolving concerns or disputes. They may or may not be binding on the parties. These were some of the first agreements to be entered into with First Nations in connection to the PTP.

\section{c. Participation or Co-operation Agreements}

These agreements are generally broader in scope. In addition to consultation or communication protocols and environmental mitigation measures, they will often include commitments regarding employment and business opportunities. They are often used in areas where only one or two Aboriginal groups are present and some sort of exclusive arrangement is appropriate.

\section{d. Impact Benefit Agreements}

These are most common for major, long-term projects. They are generally complex and binding on the parties. They often address environmental and cultural mitigation and provide some sort of financial compensation for impacts on rights, as well as support for the project. Typical provisions include communication and information-sharing protocols, recognition of Aboriginal and treaty rights, environmental mitigation measures, training and employment opportunities, economic and business opportunities, capacity building, commitments concerning cultural and traditional land use, and dispute resolution mechanisms. They may also include revenue sharing or equity participation as a form of financial compensation. The Kitimat LNG Project has negotiated forms of these agreements.

\section{COMMERCIAL CoNSIDERATIONS}

There are unique commercial considerations and arrangements that are required in the LNG context. An essential part of any LNG project is securing rights to access, construct upon, and use a site large enough for an expandable LNG facility that is near both a transportation route to permit delivery of equipment and a foreshore location that will facilitate appropriate marine loading infrastructure, that is deep enough to permit tankers to efficiently load and export from the foreshore, and is in reasonable proximity to a secure power supply source and connection to a pipeline. Meeting these needs while the front-end engineering and design work for both the facility and pipeline is still underway and a 
decision to proceed has not yet been taken, but where early works are required to be commenced to meet project schedules, requires both big picture thinking and attention to detail. Having to secure such rights from a multitude of federal and provincial government agencies and various Aboriginal groups, while concurrently negotiating marketing and joint ownership rights for a project that has not yet taken a final investment decision, requires multi-tasking of the highest order. Resolution of those challenges is fundamental to the project's success, and a final investment decision cannot be made without having the requisite agreements in place that render certain all the material economic and risk factors that have to be taken into account in making such a decision. Accordingly, a considerable amount of strategic thinking, contingency planning, and innovative drafting is required to accommodate circumstances not commonplace in traditional joint venture arrangements.

In the case of the Kitimat LNG Project, some of those requisite agreements included the Haisla Benefits Agreement, the Commercial Lease, the Foreshore Lease, the Interim Regulatory Agreement, several ownership and operating agreements between the Kitimat LNG Projects' proponents pertaining to the joint development, ownership, and operation of each Kitimat LNG facility and the PTP, the PTP Benefits Agreement, a cross charge agreement to securitize interests over the Kitimat LNG Project in the event of default, and various marketing and coordination agreements relating to the sale of LNG to foreign buyers.

The following explores some of the principal considerations in developing some of the agreements that have been executed for the Kitimat LNG Project.

\section{A. Terminal Site}

\section{The Haisla Benefits AgreEment}

The Kitimat LNG facility is located on the Haisla Nation reserve lands and much of its associated infrastructure is located on or in the vicinity of their traditional Aboriginal territory. As a result, the Haisla Nation and the Joint Owners entered discussions for an IBA. Before coming to an agreement, however, there were several key considerations that were the subject of much negotiation between the parties. The resulting Haisla Benefits Agreement needed to provide for the continued support of the Haisla Nation for the Kitimat LNG Project in dealings with the government and the public.

The most common form of consideration in such IBAs includes financial payments, community and social programming, economic development, and environmental stewardship. Participation in the project itself is also increasingly becoming a key consideration in the negotiation of IBAs for many First Nations. Participation in an LNG project can take many forms, such as a working interest, an investment interest, or employment and procurement opportunities. In many ways, the benefits will be determined by the applicable First Nation's objectives. For example, negotiations with the Haisla Nation needed to address their interest in the long-term economic development of the Haisla community through procurement and employment opportunities (including training) and community and social programming, while also providing for environmental stewardship. 
Due to the nature of the benefits considered by the Haisla Nation, a key implementation issue concerned their ability to monitor and ensure the Joint Owners' performance of such obligations. To adequately address such an issue, the parties considered whether to establish a working group comprised of representatives of both the Joint Owners and the Haisla Nation. The parties also considered how the working group would review and report to the parties on progress made toward meeting the IBA obligations. Although the underlying purpose of such a working group would be to ensure performance of the various benefits provided for in an IBA, it could also afford an increased level of First Nations participation through the management and oversight of the implementation of the benefits. Ultimately, such engagement helps facilitate the level of involvement and participation increasingly sought by First Nations in such projects.

\section{THE COMMERCIAL LEASE}

Securing tenure on the Haisla Nation lands through the Commercial Lease raised a number of unique challenges not typically faced in a traditional industrial site lease negotiation. They included: (1) acquiring a long-term lease with sufficient flexibility to accommodate the conduct of early works while addressing the lessor's concern that the lands not be undeveloped, or worse, partially developed and rendered unusable; (2) anticipating future events and addressing the parties' respective concerns (for example, suspension of work and cessation of commercial operations, a request for decommissioning plans, and mitigation of potential environmental matters without yet fully knowing what would be built or how it would be regulated); and (3) managing concerns about the long-term financial viability of the lessee and its financers given the magnitude of the investment, potential for assignment, and market changes. Overcoming the challenges in resolving such issues not only prior to a final investment decision being made, but also without certainty about all of the details underlying the ultimate design, development, construction, and operation of the Kitimat LNG facility required all parties to fully appreciate the others' concerns and to work together to create solutions that would anticipate and address all of the parties' interests. Accordingly, efforts were focused on developing an all-encompassing agreement that provided both certainty and flexibility as required by both the lessor and the lessee.

In balancing each party's objectives, negotiations needed to consider how to minimize KM LNG's financial exposure in advance of a final investment decision, while maximizing the lessor's return and access to security in the event KM LNG defaulted or an unremediated environmental issue arose. Comprehensive understanding of each party's interests and creative drafting was required in order to strike the right balance between certainty and return on the one hand, and desired flexibility on the other.

Because the term of such a lease must be tied at least to the duration of the LNG sale contracts and NEB export licence, and the cost of construction needed to contemplate financing, assignment provisions that permitted changes in control and assignments to affiliates and other third parties (including lenders under mortgages that would otherwise require the consent of the lessor) needed to be facilitated.

To address the lessor's interest in environmental oversight throughout the term of the Commercial Lease, and to ensure that end-of-term contamination and remediation issues 
were minimized, the parties examined whether periodic environmental reporting and proactive assessment and remediation requirements would be of use.

Addressing the request for up-front decommissioning plans presented another challenge. Not only were there no immediately apparent decommissioning laws for a facility that had not yet been designed or built in Canada, there was no regulator legislatively (or contractually) yet empowered to enforce such laws on First Nations lands. Accordingly, anything agreed to by the parties at that point would undoubtedly be flawed and incomplete. So, the parties considered alternatives, such as an undertaking to provide a plan as the project progressed, with economic remedies in the event of default.

Negotiations of the Kitimat LNG facility Commercial Lease were inescapably influenced by the balance that needed to be achieved between KM LNG's tolerance for risk prior to the final investment decision and need to render its obligations certain and AANDC's desire for adequate compensation and fulsome security regardless of whether a positive or negative final investment decision was taken. The achievement of that balance was a critical milestone in the Kitimat LNG Project's progression.

\section{THE FORESHORE LEASE}

To gain access to the terminal site from the water, as well as construct the necessary infrastructure in the foreshore, the proponents of the Kitimat LNG Project required a lease of the foreshore adjacent to the terminal site with terms that would be aligned, to the greatest extent possible, with those in the Commercial Lease. The greatest challenges to achieving any such alignment lay in the distinct differences between a watery foreshore and lands designated for industrial development and the fact that not only were the two premises owned by different parties, but they were also subject to different legislative regimes. As the provincial government has jurisdiction over the foreshore of the British Columbia coast pursuant to the British Columbia Land Act, ${ }^{45} \mathrm{KM} \mathrm{LNG}$, as lessee, was required to negotiate and enter into the Foreshore Lease with the Province of British Columbia (the lessor). The Foreshore Lease needed to grant KM LNG sufficient access to the foreshore in order to conduct pre-development activities and construct the requisite marine infrastructure.

Because KM LNG's requirements for the Foreshore Lease were similar to those of the Commercial Lease, it became clear that negotiations for the Foreshore Lease needed to address many of the same lessee rights with respect to access, term, early termination, and decommissioning as existed in the Commercial Lease, but without duplicating cost and liability for KM LNG. Further, the province was also looking to protect itself in the event of a negative final investment decision and sought rights not dissimilar to what was negotiated with AANDC under the Commercial Lease. As a result of the similarity between the Foreshore Lease and the Commercial Lease, many of the key considerations were approached in the same manner, albeit with slight differences. Due to the mutual exclusivity of the leases, complexities arose in ensuring there was appropriate interplay between the two agreements. For example, what should happen if one of the leases were to terminate for any 
reason — would the other lease still be required or should termination of one trigger termination of the other?

Obligations around decommissioning the Kitimat LNG Project were also considered independently. Although the decommissioning of a facility and its associated infrastructure and improvements is commonly required upon termination of any lease, the Foreshore Lease needed to address standards that reflected the sensitivity of the foreshore's aquatic environment and potential impact on surrounding waters. Such standards simply reflect the additional cost of doing business on the west coast.

\section{AGREEMENTS BETWEEN THE JOINT OWNERS}

Because LNG export projects are complex and require large amounts of capital, such projects typically involve multiple participants in the form of a joint venture or partnership. The Kitimat LNG Project is no exception. The Kitimat LNG Project requires several agreements to govern its ownership and operation. One of the most important of such agreements is the Kitimat JOA, which deals with most commercial issues, including several that are critical to the construction, ownership, and operation of the Kitimat LNG facility. Securing joint ownership and operating terms before a final investment decision is taken, before other proponents join the project, and before any other commercial agreements were entered into, may sound counterintuitive, but proved to be very strategic in setting the framework and rules of engagement on which the Kitimat LNG facility would be governed and other parties could participate.

The unique nature of the Kitimat JOA required equally unique drafting considerations. Thought needed to be given to the nature and level of support, assistance, and cooperation required by KM LNG from the Joint Owners in the construction and commissioning of the Kitimat LNG Project into commercial operation, even though the terms on which construction would occur were not settled. Capacity rights, dedication of gas reserves or production, allocation methodology of LNG, as well as lifting and balancing all required consideration. Equally important were the provisions relating to the management of the facilities upon commencement of commercial operations.

As might be expected, considerable attention in this and other agreements needed to be given to the assignment and default provisions. Because the Kitimat LNG Project is so complex, requires such large amounts of capital, and may be linked to long-term, relationship-based LNG sales agreements, the Joint Owners required the ability to manage the assignment by a joint owner of all or portions of their interests at various points in the evolution of the Kitimat LNG Project, including enabling joint owners to step away from the project prior to or upon the final investment decision, to facilitate participation by LNG buyers should the need arise, and to address potential issues relating to assignments of interests after any election to proceed. Defining the assignment rights is complicated, in part because of the large number of agreements and because it requires an understanding of the impact of assignments on all of the related agreements and relationships to ensure that ownership of an integrated project remains integrated after, as well as before, the assignment. 
Given such complexity, control over the number of owners, the percentages held, the interest that may be assigned, and who could become an owner, were all important topics of discussion. Two of the many questions surrounding assignments that required strategic thought included: (1) should minimum interests be held to help mitigate the potential for minority interest owners ending up with a potential veto over certain decisions; and (2) should the assignable interest contemplate not only the LNG facility but also mandate a corresponding interest in all related infrastructure and contracts in order to preserve the integrated nature of the project?

In addition, given these factors, the capital intensity of the Kitimat LNG Project, and the long-term nature of LNG sale contracts, consideration needed to be given to the types of controls permitting assignment and how a major default would be managed. Those issues led to discussions over the type of creditworthiness requirements and the form and amount of security that would be appropriate if an owner or assignee failed to meet certain minimum tests. Would a buy-out right at a discount to fair market value sufficiently secure a nondefaulting party's or operator's right to force a defaulting party to sell its interest at a discount if they failed to cure ${ }^{46}$ What kind of default and failure to cure would trigger such a right, if it existed? What are the risks to enforcement of such a right if reliance is critical to ensuring the principal objective that no party should have to finance the other party's obligations? All of these issues are important considerations for every major project, but were made even more important by the fact that the non defaulting parties needed to perform the sellers' aggregate obligations under LNG sales contracts.

\section{B. Pacific Trail Pipelines Considerations}

\section{ALIGNING OWNERSHIP INTERESTS WITH THE KITIMAT LNG FACILITY}

The PTP rights of way and permits are held by Pacific Trail Pipelines Limited Partnership (PTP LP), whose limited partners include the Joint Owners and, up to March 2011, Pacific Northern Gas Ltd. (PNG), a public utility that was also the managing partner and operator of PTP LP. In addition, FNLP has an option to acquire an equity interest in PTP LP under the PTP Benefits Agreement.

Natural gas pipelines are common undertakings, but the unusual commercial considerations of the PTP reflected the fact that integration of the engineering, design, construction, and operation of the PTP and Kitimat LNG facility were required to ensure that the LNG production, storage, lifting, balancing, sales, and shipping activities and obligations will be satisfied even where ownership of the pipeline was not fully aligned with ownership of the LNG facility. The PTP has to be engineered, designed, built, and operated within the specifications, timelines, and cost parameters of the Kitimat LNG Project as a whole, ideally with consistent and coordinated ownership. Accordingly, the proponents adopted a strategic approach to overcome the challenges of: (1) coordinating the timing of permitting, engineering, design, and construction activities; (2) aligning the ownership interests of the Kitimat facility and the PTP; (3) developing cross charge security arrangements among the

46 Another consideration is, if such rights exist, how should they interact with similar remedies under the Cross Charge and Default Agreement (CCDA)? 
owners across all of the Kitimat LNG Project elements; and (4) developing operating and balancing arrangements that coordinated the operation of all elements.

In developing a mega project with different ownership interests and unique considerations on either side, having the ability to oversee and direct the coordinated timing of all of the elements so that the pieces do not pull too far ahead or behind each other is vital. In this case, with two distinct ownership groups and, originally, two different operators, the original parties sought to manage this on a macro scale with an agreement setting forth the conditions precedent that each project element was subject to before proceeding through various steps of advancing the permitting, engineering, financing, and construction of that project element (the Precedent Agreement). The Precedent Agreement served to connect the two elements of the project and to move them forward at a coordinated pace.

Until March 2011, PNG held the majority interest in PTP LP. Although the raison d'être of the PTP was to deliver natural gas to the Kitimat LNG facility, there was a misalignment between the two components, as PNG had no ownership interest in the Kitimat LNG facility. Given the importance of the PTP to the Kitimat LNG Project, the alignment of ownership interests became necessary for the proponents to gain tighter control over timing, costs, alignment of front-end engineering and design, and ultimately, over the operation of the Kitimat LNG Project in an integrated fashion. As a result, in March 2011, the Joint Owners acquired PNG's entire interest in PTP LP and aligned both ownership and operatorship of the two components of the project.

\section{PTP BENEFITS AGREEMENT}

The pipeline route extends over a significant distance and crosses the traditional lands of 16 First Nations. As a result of an extraordinary initiative by First Nations' members and the government of British Columbia, 15 of those diverse First Nations joined together to form FNLP, a limited partnership, to provide a single First Nation's voice on matters relating to the PTP. The challenge and success of creating FNLP cannot be overstated. Consultation with each First Nation for new approvals and permits in respect of their individual Aboriginal rights continues to be required; however, the establishment of FNLP facilitated the negotiation and execution of a single IBA that considered participation rights and economic opportunities along the pipeline route for the members of FNLP. The PTP Benefits Agreement was signed 4 February 2011 between FNLP, PTP LP and Pacific Trail Pipelines Management Inc. (the general partner of PTP LP). This agreement and the ongoing communication with FNLP about the PTP reflect the recognition by PTP LP and FNLP of the long-term nature of their relationship given that the pipeline will be located on lands subject to the First Nations' Aboriginal rights for the life of the PTP.

\section{REQUIREMENT FOR CROSS CHARGE SECURITY}

In a project as integrated as the Kitimat LNG Project, where return on the significant capital investment made by all parties in reserve development, pipeline and LNG facility construction, and development of storage and marine export facilities is not realized until payment for the sale of LNG is received by the operator under LNG sales contracts, it is imperative for the operator to be able to deliver sufficient volumes of LNG to meet the 
aggregate commitments to the buyer without taking on the risk of having to finance its partners' obligations in the event of default. As default can occur at varying points in the life of the Kitimat LNG Project, and given that each project element is governed by a separate agreement (for example, the Kitimat JOA, PTP Partnership Agreement, and upstream reserves JOA), the parties determined that a CCDA that secures each party's interest in the pipeline, LNG facility, and all related facilities and contracts, would be advisable. The purpose of such an agreement is to create an overarching right of the operator as collateral agent, and of the non-defaulting parties, to exercise certain remedies in the event of default anywhere along the supply chain so that efforts to mitigate against default under the LNG sales contract can be effective deterrents to prolonged or major defaults.

\section{UPSTREAM CONSIDERATIONS}

For the Kitimat LNG Project, the unique challenges attributable to coordinating LNG development extended upstream to the development of the respective reserves held by the proponents. As each Joint Owner has significant 100 percent owned acreage in the Horn River Basin, there are no existing joint operating agreements for the upstream gas supply that is dedicated by virtue of the Kitimat JOA. Nor is there a model form operating procedure that works well for shale gas development in Canada, should participation be offered to or required by LNG buyers. While many standard clauses can be used from either the Canadian Association of Petroleum Landmen (CAPL) or Association of International Petroleum Negotiators (AIPN) model form operating procedures, ${ }^{47}$ both require extensive modifications to meet the unique requirements of a shale gas project, most notably because shale gas is a relatively new technology that is still evolving and the projects are capital intensive. ${ }^{48}$ Consequently, regardless of which model form agreement may be used as the starting point, the unique considerations that have to be taken into account include the need to address independent operations, security, operator liability and indemnity, how the operator recovers overhead costs, construction and ownership of joint facilities (as these are major infrastructure projects), the pace of development, default provisions, and how decisions are made.

\section{AIPN VERSUS CAPL MODEL Form AGREEMENTS}

The two most common model operating agreements that have been used for shale gas projects are the AIPN JOA and the CAPL Operating Procedure. Neither is perfect, and there are pros and cons to using either agreement as a starting point. The AIPN JOA is a model agreement that is used internationally and, therefore, may be more familiar to many of the new international participants in unconventional development projects. The CAPL Operating

47 See CAPL, 2007 CAPL Operating Procedure (Calgary: CAPL, 2007), online: CAPL <http://www. landman.ca/landman_tools/operating_procedure2007.php> [CAPL Operating Procedure]; AIPN, International Operating Agreement (JOA) 2012 (Houston: AIPN, 2012) [AIPN JOA].

48 Despite the AIPN's release of the 2012 AIPN JOA, ibid, the Guidance Notes published for it indicate that it is not designed to accommodate industry practices with respect to shale gas and other unconventional gas projects and refers the drafter to the annotations at the end of the 2007 CAPL Operating Procedure, ibid, in which a range of issues is discussed. Such notes also suggest: modifying the requirement that development wells be part of an approved development plan or that exclusive operations may not be conducted during development and production; allowing contingent drilling; specifying criteria for use of technology for horizontal drilling; setting out consequences of varying depth and horizontal length of well; and allowing use of infrastructure. 
Procedure is more familiar to domestic participants, and thus to many of the proponents, employees, and contractors who will actually be working with the JOA on a daily basis. A difficulty with the CAPL Operating Procedure is that it focuses on projects on a well-by-well basis. While the AIPN JOA also contemplates well-by-well projects, it incorporates the concept of a work program and budget that is easier to use for the type of large project development needed for a shale gas project. One recent modification of the CAPL Operating Procedure that is beneficial for unconventional projects is the addition of the horizontal well provisions often used in shale gas development. ${ }^{49}$ As noted, the AIPN JOA has not yet been amended to reflect industry practices for unconventional gas development projects. ${ }^{50}$

Ultimately, either of these forms can be used as a starting point and their use depends on the preference of the parties involved. Regardless of which one is chosen, the parties will need to consider numerous modifications to either agreement to make it workable for a shale gas project, some of which are discussed below.

\section{ModificATIONS TO THE MODEL Form AgREEMENTS}

\section{a. Independent Operations}

First, the independent operations provisions are drafted for conventional operations and thus are not sufficient to deal with the capital intensive nature of shale gas projects. As such projects require pad drilling, the parties need to consider what reasonable limits should be placed on a party's ability to propose independent operations to ensure that the other parties are not spent out of the play. One solution is to limit the number and size of independent operations that can be proposed in a given year. Another solution is to impose a delay between when an independent operation is proposed and when it will be commenced, in order to allow the other parties time to consider and budget for the proposed independent operation and allow for the possibility that it will be included in the next annual work program and budget. In addition, the parties will need to consider what penalties should be imposed to balance the need for the participating parties to recover their expenditure and be compensated for the risk of participation while making it financially viable for nonparticipating parties to re-enter the project, if desirable.

\section{b. Management and Approval of Projects}

A second but related issue is how to manage and approve capital intensive projects that require significant time and resources. Parties will need to consider the use of a management committee rather than each party individually approving each authority for expenditure (AFE), as is the case with the CAPL Operating Procedure, and if a project can be approved with only a simple majority approval (51 percent), or if some other approval threshold will be necessary given the size and nature of the project. When determining the approval threshold, the parties should ensure that such voting thresholds will still work if new parties are added or if parties leave the JOA. The use of work programs and budgets allow the parties to better manage the size and scope of these projects, rather than an AFE for each 
individual project. As well, once a work program and budget is approved, the parties will need to consider if a party will be permitted to not participate in a project or if all parties will be required to participate once the work program and budget is approved by the management committee, even if that party did not vote in favour of such operations.

Another consideration is the consequences that flow from parties failing to agree on a project. One option is to automatically characterize such a project as an independent operation, so as not to sterilize the land. Mechanisms to ensure that sterilization does not occur because of indecision or disagreement among the parties will be required. These could include: options to perform independent operations even if it is outside the work program or development plan if there has been no new development over a number of years; the continuation of the previously approved work program and budget until a new work program and budget is approved; or a set budget to be used by the operator to continue development even if a new budget is not approved due to deadlock in the management committee.

A challenge with managing operations is how to maintain flexibility for the operator in the development of the project. As the technology is continually developing and the operator may discover new information as the project proceeds, the operator will need to be given a degree of flexibility in an operation once it is included in a work program and budget. Certain over-expenditures or changes to the project may be required and, as such, the JOA should not constrict the operator from making changes as the project progresses by requiring a full management committee approval for each change. This can be addressed with a threshold for over-expenditures on the budget requiring a new approval and a clause allowing changes to the work program if the operator feels these changes are necessary and in accordance with either good oilfield practices or industry standards.

As these are pad drilling projects and take longer than conventional drilling, how to manage the timeline for development needs to be addressed. Under a work program and budget, the parties will be able to plan yearly projects without requiring approval for each piece of the project through an AFE. The parties may consider the use of an overall development plan that takes a longer term, multi-year perspective of the development of the area. The development plan can be used as a guideline for the yearly work programs and budgets, and to govern independent operations to ensure that an independent operation does not hinder joint operations because of spacing requirements or other issues. Flexibility to amend the development plan as new regulations or technologies emerge should be maintained through yearly reviews of the development plan so that it still meets the needs of the general program.

A final consideration in the management and approval of operations is how the operator will recover overhead costs for such capital intensive projects. One option is to require each party to provide security through a letter of credit or other means that the operator can draw down on to pay the overhead costs. Another option is to require the parties to pay their full working interest share of each budget within a certain timeframe after the approval of the budget, where failure to pay by the deadline will be a default under the JOA.

Finally, the parties will need to determine what the remedies of default will be, as the traditional remedies found in conventional JOAs may not be adequate given the potential 
magnitude of the default and the associated consequences to the non-defaulting parties especially if serving as the gas supply for an integrated LNG project.

\section{c. Joint Facilities}

A third consideration in drafting is how to manage the construction of facilities, as shale gas projects require major infrastructure compared to the joint facilities used in conventional drilling. The standard joint facility language in the AIPN JOA or CAPL Operating Procedure is inadequate for these types of projects. The parties will need to consider what facilities should be approved under these agreements or be the subject of a separate construction, ownership, and operating agreement, how facilities will be approved, if a party can opt out of participation in a facility, whether such facility can be constructed and owned as an independent operation, and how the facility will be managed. If the facilities will be operated through a separate agreement, the parties will need to draft requirements for such separate agreements to be entered into after approval of the facility, and, to reduce the need for negotiation of such separate agreement, append a form of the agreement to be used to the JOA.

\section{FLEXIBILITY OF THE JOA}

Maintaining flexibility of terms will be important in order to accommodate evolution in technology and regulations governing unconventional drilling projects and allow for parties to be added or depart. The JOA must be flexible enough to allow for such evolution without requiring amendment of the JOA for each new technological development or amended regulation. As well, voting thresholds and the management committee parameters must be flexible enough that changes to the parties to the project can be made without requiring the JOA and management structure to be amended.

Thinking ahead to accommodate the participation by one or more parties who may be offtake buyers rather than conventional western Canadian joint operators and the impact on or differences between an acceptable pace of development and how differences are to be resolved may be important to the longevity of the project. LNG buyers who enter into 20year LNG sales contracts and elect to participate in the upstream development bring a longterm view to such development and to who their partners are. As understanding the development of such reserves may also be critical to their supply and demand particulars, short-term monetization of such right is not usually a consideration.

\section{NEB EXPORT AUTHORIZATIONS}

\section{A. BACKGROUND TO THE EXPORT LICENCE REQUIREMENT}

No LNG export project in Canada can be realized without obtaining an export authorization from the NEB. These authorizations take one of two forms: (1) a short-term export order, which allows a person to export natural gas for up to two years in any volumes or for a term of between two years and 20 years for volumes of up to 30,000 $\mathrm{m}^{3}$ per day; or, (2) an export licence, which may be granted for a maximum of 25 years and for any volumes. Short-term export orders are granted under the National Energy Board Act Part VI (Oil and 
Gas) Regulations ${ }^{51}$ and will be granted by the NEB if they are determined to be in the public interest. ${ }^{52}$ In contrast, the legislative test for an export licence is contained in section 118 of the NEB Act:

On an application for a licence, the Board shall have regard to all considerations that appear to it to be relevant and shall

(a) satisfy itself that the quantity of oil or gas to be exported does not exceed the surplus remaining after due allowance has been made for the reasonably foreseeable requirements for use in Canada having regard to the trends in the discovery of oil or gas in Canada; and

(b) [Repealed, 1990, c. 7, s. 32]

(c) where oil or gas is to be exported and subsequently imported or where oil or gas is to be imported, have regard to the equitable distribution of oil or gas, as the case may be, in Canada. ${ }^{53}$

Therefore, the NEB must not only determine if a proposed export licence is in the public interest, but it must also look at any other considerations that it deems relevant and determine if the proposed export is surplus to Canadian domestic requirements. This latter requirement is referred to as the "surplus test."

The export licence requirement for natural gas dates back to the original enactment of the NEB Act in $1959 . .^{54}$ At the time, the primary rationale behind licencing natural gas exports was to protect domestic requirements, maintain low domestic prices, ensure that Canadian producers' and exporters' interests were protected, and to ensure that by-products such as sulphur, liquefied petroleum gases, and natural gasoline were brought to market and not wasted. ${ }^{55}$ In the Royal Commission on Energy’s 1958 Borden Report, the purpose of which was to develop national policies in relation to energy and energy exports, the Royal Commission states that:

Each application for a licence to export natural gas must be reviewed in the light of the fact that Canada is dependent on its own resources for its supply of gas. The Commission is of the opinion that, if the granting of an export licence would in any way interfere with the supply of the reasonably foreseeable natural gas requirements of those parts of Canada within economic reach of the producing provinces, permission to export should be withheld. ${ }^{56}$

SOR/96-244, s 15(a) [Part VI Regulations].

The public interest standard used by the NEB to assess long-term gas export authorizations have been informed by its Market Based Procedure. As noted, the Market Based Procedure is designed to establish whether a proposed export of natural gas is surplus to reasonably foreseeable Canadian requirements, having regard to the trends in the discovery of natural gas in Canada. Elements of the Market Based Procedure are now being modified in light of the introduction of the Jobs, Growth and Long-term Prosperity Act, supra note 10.

Since the preparation of this article, section 118 of the NEB Act was modified following the passage of the Jobs, Growth and Long-term Prosperity Act, ibid. As noted supra note 10, the NEB is now consulting with industry as to whether, and if so how, its former Market Based Procedure should be modified in light of the introduced changes in legislation.

SC 1959, с 46.

Royal Commission on Energy, First Report (Ottawa: Royal Commission on Energy, 1958) at 11-12 [Borden Report].

Ibid at 10 . 
This rationale was likely grounded in the fact that the first exports of natural gas from Canada in the late 1800s resulted in such extensive depletion of Canadian natural gas reserves that domestic demands were unable to be satisfied. ${ }^{57}$ Therefore, according to one commentator, export controls for natural gas were deemed necessary because "natural gas is almost unique among Canadian energy resources for the simple reason that a domestic market may be capable, in the not-too-distant future, of absorbing all economicallyaccessible production. This is quite unlike coal which arguably exists in such vast quantities that the value of serving an export market is almost unassailable." 58

Originally, the surplus test was satisfied through a formula calculating the current natural gas demand in Canada and multiplying that by 25. Any volumes over and above this amount were determined to be "surplus" which could be exported. ${ }^{59}$ The surplus formula was subsequently modified in 1986 to a reserves to production ratio of 15 . Again, any reserves above this ratio constituted surplus reserves. ${ }^{60}$ However, the NEB departed from a strict formula approach to the surplus test in 1987, following the Agreement on Natural Gas Markets and Prices ${ }^{61}$ between the governments of Canada, Alberta, British Columbia, and Saskatchewan that deregulated natural gas prices across Canada. In its GHR-1-87 Decision, ${ }^{62}$ the NEB set out the "Market-Based Procedure” (MBP) for determining whether natural gas to be exported under a licence was surplus to reasonably foreseeable Canadian requirements. For the past 25 years, the MBP has been used by the NEB for all export licence applications to determine whether the surplus test is satisfied.

The MBP consists of two parts: public hearings for specific export licence applications and ongoing monitoring of the Canadian energy markets by the NEB. The public hearing aspect of the MBP has three separate components: (1) a complaints procedure to ensure that no Canadian consumer is in a position of not being able to obtain supplies of natural gas under contract on similar terms and conditions, including price, to the proposed export; (2) the preparation of an export impact assessment that determines whether the proposed export will be likely to cause Canadians difficulty in meeting their energy requirements at fair market prices; and, (3) a public interest determination whereby the NEB may consider any other factors it considers relevant in determining whether the proposed export licence is in the national public interest. These considerations include assurance of takes, durability of export sales contracts, the arm's length nature of the contracts, producer support, adequacy of supply, transportation cost recovery, and assessment of the appropriate term of the licence. ${ }^{63}$ In addition, as will be explained in greater detail below, under section 118 of the Act the NEB may consider environmental effects that are "necessarily connected" to the proposed export.

Ian McDougall, “The Canadian National Energy Board: Economic 'Jurisprudence' in the National Interest or Symbolic Reassurance?” (1973) 11:2 Alta L Rev 327 at 334. Ibid at 328.

RJ Gibbs, DW MacFarlane \& HJ Knowles, “A Review of the National Energy Board Policies and Practices and Recent Hearings” (1971) 9:3 Alta L Rev 523 at 537.

NEB, Reasons for Decision in the matter of Phase 1: The Surplus Determination Procedures Phase of the Gas Export Omnibus Hearing, 1985 (April 1986), NEB Decision GH-2-85 at 32.

Signed 31 October 1985.

NEB, Reasons for Decision in the Matter of Review of Natural Gas Surplus Determination Procedures (July 1987), NEB Decision GHR-1-87 [GHR-1-87 Decision].

NEB, Reasons for Decision: Proposed Changes to the Application of the Market-Based Procedure (May 1992), NEB Decision GHW-1-91 at 11. 
The NEB has explained the underlying premise of the MBP as follows:

The underlying premise of the Market-Based Procedure is that, while flexible prices may be normally expected to provide for an adequate balance of supply and demand over time, market failure can occur and there is a need for the Board to assess the likelihood of this happening. Difficulties of adjustment between different levels of supply or demand are in themselves instances of market failure, hence the importance of a mechanism to help identify whether such difficulties may be expected to occur. ${ }^{64}$

Therefore, the MBP allows the market to dictate prices and the overall supply and demand balance, but it recognizes that a certain degree of oversight by the NEB is necessary to ensure that domestic demands are met.

Since deregulation of the North American natural gas industry in the mid-1980's, industry has largely avoided the more onerous export licence requirements and has instead preferred "evergreen" short-term export orders. This is because market participants can obtain longterm certainty of supply simply through access to liquid markets that are connected to the broader continental natural gas grid. Short-term export orders allow companies to export unlimited volumes for a two-year period following an application that is typically processed in a matter of days. These short-term export orders can then be easily renewed at the end of the two-year term. In contrast, based on the "surplus test" requirement in section 118 of the NEB Act and the MBP, export licences typically take 10-12 months to obtain. Between 2000 and 2010, only one application for an export licence was filed with the NEB.$^{65}$ Given the nature of such process, and the fact that the licence is not assignable, the parties quickly concluded that filing such application and obtaining the licence under the operator's name would be efficient and more cost effective than each owner applying for its own export licence.

\section{B. The Paradigm Shift: EXPORT LiCENCES AND LNG ProJects}

Unlike market participants in North America, who can purchase large volumes of natural gas at liquid hubs to meet short-term needs, LNG buyers, particularly in the Asia Pacific market, rely upon long-term LNG sale and purchase agreements (SPAs) to meet their natural gas demands. Short-term export orders from the NEB are unlikely to provide these buyers with the long-term supply certainty that they seek. Therefore, export licences are back in fashion amongst potential LNG exporters in Canada. However, several aspects of the NEB's historical treatment of export licences are challenged by LNG export projects, which typically involve new market expectations and demands, new and unconventional supply sources, and new environmental considerations associated with export via marine tankers. Therefore, KM LNG's application for an LNG export licence included a request that the NEB modify its traditional requirements for export licences in the context of LNG, in order Impact Assessment Filing Requirements (November 1989) at 4.

65 Repsol Energy Canada Ltd, Application for Long-term Licenses to Import Liquified Natural Gas (LNG) and Export Natural Gas, NEB Hearing Order GH-1-2008 (submitted 27 December 2007). 
to allow LNG export projects from Canada to succeed. ${ }^{66}$ The following discussion highlights the innovative approach taken in the application for the Kitimat LNG Project export licence.

\title{
1. NEW MARKET EXPECTATIONS AND DEMANDS
}

One of the primary differences between the North American natural gas market and the Asia Pacific LNG market is the sensitivity of buyers around public disclosure of export sales contracts. The NEB has historically required such disclosure as part of the complaints procedure to allow market participants in Canada to understand the terms of a proposed export, including price, and determine whether they have the ability to contract on similar terms. Section 12 of the Part VI Regulations ${ }^{67}$ specifically requires that all applications for natural gas export licences include copies of all export sales contracts. This type of disclosure, however, is likely unacceptable to LNG buyers, as it is inconsistent with the level of disclosure in other jurisdictions. ${ }^{68}$ In the Kitimat LNG Project export licence proceeding, KM LNG testified that

KM LNG believes that requiring this [export sales contract] disclosure will seriously put at risk and frustrate marketing efforts now underway and thus disadvantage Canada from competing in markets that would otherwise have the ability to support the continued development of Canadian natural gas resources and achieve the associated regional and national economic development. ${ }^{69}$

KM LNG provided an overview of typical terms contained in LNG SPAs in the Asia Pacific region, together with LNG pricing forecasts, that showed LNG prices well above North American natural gas prices for the foreseeable future. KM LNG concluded that

\begin{abstract}
Canadians are currently able to purchase and sell natural gas at liquid hubs for short-term durations at competitive North American natural gas prices ... LNG sales contracts in the Asia Pacific market are typically for long durations, are for large quantities of LNG, involve strict take or pay obligations, and traditionally price LNG on a crude oil formula. These prices in KM LNG's SPAs [export sales contracts] will allow recovery of the significant investments that are proposed to be made to construct the project. The prices at which the LNG is sold under these gas export sales contracts will necessarily be higher than domestic North American prices over the term of the licence. If it were otherwise, the parties would not be making the investment that is now proposed. ${ }^{70}$
\end{abstract}

KM LNG thus submitted that, given the nature of the export proposal, disclosure of the export sales contracts themselves was unnecessary to satisfy the intent of the complaints procedure. Similarly, KM LNG requested an exemption from section 4 of the National Energy Board Export and Import Reporting Regulations, ${ }^{71}$ which requires the holder of every export licence to report on a monthly basis to the NEB several types of information,

KM LNG, Responses of KM LNG Operating General Partnership to Information Request No 2 of National Energy Board (1 June 2011), NEB Hearing Order GH-1-2011 (NEB Filing A1Z4Z4, A1Z4Z5, A1Z4Z6) at 59 [KM LNG Response].

Supra note 51.

Through discussions with LNG marketers in the Asia Pacific region, the authors understand that the primary competitors to Canada for LNG supply in the Asia Pacific region (namely Australia and several countries in the Middle East) do not have similar disclosure requirements.

KM LNG Response, supra note 66 at 59.

Ibid at 59-60.

SOR/95-563. 
including the price of all gas exported on a per-shipment basis. KM LNG proposed to provide aggregated information to the NEB (including export price) on a quarterly basis, combining the values from all of its export contracts.

In its GH-1-2011 Decision, ${ }^{72}$ the NEB granted KM LNG's request for exemptions from the requirements to file copies of export sales contracts and disclose export pricing information on a per-shipment basis each month. The NEB held that " $[t]$ he Board's past interpretation of surplus determination in general and the MBP in particular, has been done in a flexible manner that responded to changing market conditions,"73 and that "[g]iven that global LNG markets are characterized by long-term bilateral arrangements, the [NEB] is cognizant that adhering to the filing requirements may introduce an unwarranted level of risk for the Applicant."74 As a result, the NEB granted KM LNG's request for an exemption from filing details of gas export sales contracts and demonstrated its willingness to flexibly apply the MBP in the context of LNG exports. Since KM LNG satisfied the underlying purpose of the MBP, adherence to strict filing and reporting requirements was deemed unnecessary.

\section{UNCONVENTIONAL SUPPLY SOURCES}

A second unique aspect of LNG export licence applications is their relationship to new, unconventional sources of natural gas. These new supply sources are located both in Canada and in the United States. While the resources that are proposed to be exported will likely be sourced in Canada, the change in natural gas production south of the border has affected the fundamentals of the North American natural gas market and the way in which the surplus test is applied.

The US is currently experiencing unprecedented growth in natural gas production. The United States Energy Information Administration (US EIA) forecasts a four-fold increase in US domestic shale gas production between 2009 and 2035. ${ }^{75}$ As noted in the KM LNG response to an NEB information request:

The implications of this change in supply conditions will significantly impact the share of the US market historically served by Canadian gas supply. The US EIA's 2011 Annual Energy Outlook forecasts net imports of natural gas serving United States demand to decline eleven-fold from $11 \%$ of total required supply in 2009 to $1 \%$ in 2035. Net imports of natural gas to the United States have been primarily comprised of Canadian gas supply produced from western Canada.

The result of this forecast means that over the long-term, US natural gas supply is expected to significantly displace western Canadian gas supply otherwise available to compete in and serve traditional US export markets. $^{76}$

NEB, In the matter of KM LNG Operating General Partnership: Application dated 9 December 2010 for a long-term export licence to export liquefied natural gas under section 117 of the National Energy Board Act (NEB Act) (October 2011), NEB Decision GH-1-2011 [GH-1-2011 Decision]. Ibid at 8.

Ibid at 10 .

US EIA, Annual Energy Outlook 2011 with Projections to 2035 (Washington, DC: US EIA, 2011) at 80 [Annual Energy Outlook].

KM LNG Response, supra note 66 at 10. 
“Equally important, the US EIA's forecast also expects that the growth in US gas supply will be available to serve eastern Canadian market demand," regions of the US (for example, Pennsylvania and New York) will be available to eastern Canadian markets at a lower cost than gas produced in western Canada. ${ }^{78}$ The forecast that was prepared by Ziff Energy for the Kitimat LNG export licence application reached the same conclusions and predicted that consumers in central and eastern Canada would increasingly source their gas supplies from the US. ${ }^{79}$ This fundamental change is now being reflected in applications before the NEB. ${ }^{80}$

In western Canada, meanwhile, the same technologies that are allowing producers in the US to access new and vast natural gas supplies are unlocking tremendous supplies of their own. The NEB has forecasted that the amount of recoverable natural gas in the Horn River Basin of northeast British Columbia alone amounts to 78 trillion cubic feet (Tcf). ${ }^{81}$ Some in industry believe this number is low. ${ }^{82}$ The Montney formation in British Columbia may hold another 40 Tcf. $^{83}$ In addition, vast amounts of natural gas are believed to be recoverable in the Mackenzie Valley and the Mackenzie Delta of the Northwest Territories. The Mackenzie Gas Project that was proposed to transport these volumes to market was approved by the NEB in 2010, but the project may be postponed significantly or cancelled as a consequence of the current "glut" of natural gas supply already on the continent and the resulting depressed gas prices. ${ }^{84}$

These changes in natural gas supply sources in North America have several implications for LNG projects. First, the need for Canadian natural gas producers to find new markets in order to continue developing their reserves at historic levels suggests that any LNG exports from Canada are in the national public interest. Second, the fact that Canadian consumers are beginning to source their natural gas from the US undermines the fundamental premise of requiring natural gas export licence authorizations, which is that Canadian gas consumers will be supplied exclusively with Canadian-sourced natural gas. The implications of this change will be explored further below. Finally, the immaturity of shale gas plays in Canada mean that exporters and the NEB must rely on possible and contingent resource estimates to demonstrate adequacy of supply, as opposed to the NEB's historic focus on established reserves.

$77 \quad$ Ibid.

78 Annual Energy Outlook, supra note 75 at 80.

79 Ziff Energy Group, Natural Gas Demand and Supply Forecast: North America and Canada (20102035) (Calgary: Ziff Energy Group, 2010) at 2.

80 See e.g. TransCanada PipeLines Limited, NOVA Gas Transmission Ltd \& Foothills Pipe Lines Ltd, Application for Approval of the Business and Services Restructuring Proposal and Mainline Final Tolls for 2012-2013, NEB Hearing Order RH-003-2011 (submitted 1 September 2011) and TransCanada PipeLines Ltd, Application for the 2012 Eastern Mainline Expansion (submitted 8 November 2011) (NEB Filing A35884), both of which reflect decreasing natural gas shipments into eastern Canada from the Western Canadian Sedimentary Basin.

81 British Columbia Ministry of Energy and Mines (BC MEM) \& NEB, Ultimate Potential for Unconventional Natural Gas in Northeast British Columbia's Horn River Basin (Victoria \& Calgary: BC MEM \& NEB, 2011) at 9, online: NEB < http://www.neb.gc.ca/clf-nsi/rnrgynfmtn/nrgyrprt/ntrlgs/ hrnrvr/hrnrvrm-eng.pdf>.

82 In NOVA Gas Transmission Ltd, Northwest Mainline Komie North Extension, NEB Hearing Order GH001-2012 (submitted 14 October 2011), Section 3 at 8, marketable gas from the Horn River Basin is estimated to be 104 Tcf.

83 NOVA Gas Transmission Ltd, Groundbirch Pipeline Section 52 Application, NEB Hearing Order GH1-2009 (submitted 30 April 2009), Section 4 at 4.

$84 \quad$ See NEB, Reasons for Decision, Imperial Oil Resources Ventures Ltd - MacKenzie Gas Project (16 December 2010), NEB Decision GH-1-2004. 
The NEB has recognized the need to rely on possible and contingent resource estimates to demonstrate adequacy of supply and applied its traditional requirements with respect to supply considerations flexibly in the context of LNG projects. In the Kitimat LNG Project export licence proceeding, the NEB held that:

The Board is mindful that shale gas development in northeast BC is in its infancy; however, the Board is cognizant of the large resource potential and the significant investments that companies are undertaking to develop these resources. Drilling efficiency, well performance and safety of operations continue to benefit from ongoing technological progress and are likely to further enhance potential gas supplies. It is likely that shale gas in northeast BC will represent a significant incremental source of natural gas production in the future. $^{85}$

\section{ENVIRONMENTAL EFFECTS}

A third unique consideration for LNG exports relates to the NEB's assessment of environmental effects of the proposed export under the "Other Public Interest Considerations" component of the MBP. The test that the NEB relies upon for this determination is referred to as the "necessary connection" test. This test was first established by the NEB in its GH-5-93 Review Decision, which stated that the NEB will consider the environmental effects of a proposed export so long as there is a "necessary connection or proximity between the environmental impacts to be assessed [by the Board] and the federal decision making power being exercised." 86

In the context of natural gas export licences, the test has historically only been applied to upstream activities, since any downstream environmental effects associated with export pipelines would be outside Canadian jurisdiction. Although the existence of a necessary connection will depend on the facts in each case, the NEB has stated that a necessary connection requires the "export licence and new upstream facilities or activities [to] be integrated to the extent that they can be seen to form part of a single course of action." ${ }^{87}$ In general, a necessary connection will not exist to include upstream production facilities or activities when the applicant intends to draw on gas supply from a number of possible sources to serve the export (for example, a corporate supply portfolio) ${ }^{88}$ However, a

GH-1-2011 Decision, supra note 72 at 13. See also NEB, In the matter of BC LNG Export Co-operative LLC's Application dated 8 March 2011 for a long-term export licence to export liquefied natural gas under section 117 of the National Energy Board Act (February 2012), NEB Decision GH-003-2011 at 14 [GH-003-2011 Decision]. We note that the proponent had no natural gas supplies of its own; rather, the proponent relied on a co-operative arrangement in which gas producers had the ability to nominate gas periodically for export through the project. Back-up supply contracts with gas providers would make up any shortfall for a particular period. Despite the fact that the NEB has historically relied upon firm supply commitments for any export licence application, the NEB concluded generally that there was adequate supply to support the export volume over the term of the applied-for licence. Further, even though BC LNG had only acquired transportation capacity for roughly half of the proposed export, the NEB concluded that "BC LNG has sufficient incentive to ensure that additional pipeline capacity to the Terminal will be acquired in order to fully utilize the export volumes requested in this Application" (ibid).

86 NEB, Reasons of Decision in the Matter of Review of the Applications for Gas Export Licences from Brooklyn Navy Yard Cogeneration Partners, LP, Husky Oil Operations Ltd, ProGas Limited, Shell Canada Limited, Western Gas Marketing Limited (June 1994), NEB Decision GH-5-93 at 21.

87 NEB, Reasons for Decision in the matter of CanStates Gas Marketing, Chevron Canada Resources Limited, Renaissance Energy Ltd and Western Gas Marketing Limited Applications Pursuant to Part VI of the National Energy Board Act for Licences to Export Natural Gas (November 1994), NEB Decision GH-3-94 at 23. Ibid at 22-23. 
necessary connection will likely be found if there is a contractually dedicated supply source being used to satisfy the requirements of the export licence. ${ }^{89}$

In the LNG context, there are two important considerations related to the necessary connection test. First, in its recent decisions regarding LNG export licences, the NEB has determined that downstream LNG shipping meets the necessary connection test for LNG export projects. This allows the NEB to consider any environmental effects associated with LNG shipping in the context of an export licence proceeding. The circumstances in which the Board will consider such effects, however, and the scope of that consideration, has yet to be determined. Second, LNG buyers in the Asia Pacific market have traditionally expected dedicated natural gas reserves as part of any LNG export proposal in order to ensure longterm supply certainty. If such a proposal were pursued in Canada, a necessary connection would likely exist. Since the extent to which the NEB will consider upstream environmental effects in a particular application depends on the circumstances and cannot be definitively predicted in advance, the existence and continuation of a necessary connection standard will add regulatory uncertainty to a proposed LNG export project.

In the Kitimat LNG export licence proceeding, KM LNG stressed that natural gas for the proposed export would be sourced from its partners' corporate supply pools and would not be dedicated from any particular development. The NEB accepted this evidence as demonstrating that no necessary connection existed between the proposed export and any particular upstream development, such as the Horn River Basin. However, the NEB stated that even if there were such a necessary connection, "there is a comprehensive regulatory and environmental assessment scheme that will consider environmental and socio-economic effects related to development in the Horn River Basin." 90 Similarly, for downstream shipping activities, the NEB concluded that "potential environmental effects and directly related social effects have been considered in the Joint EA [environmental assessment] or will be considered through TERMPOL.... [T] he Board is of the view that duplicating the work conducted under the relevant federal and provincial legislation and processes is not warranted."91

Therefore, even though the NEB found that a necessary connection existed between the applied-for export licence and downstream LNG shipping, it opted not to conduct its own assessment of the environmental effects associated with those activities so long as the effects were considered through other regulatory processes. This decision has transformed the necessary connection test into a two-part test where the NEB must conclude that: (1) there is a necessary connection between the proposed export and certain environmental effects, and (2) there is no comprehensive regulatory and environmental assessment scheme in place to assess those effects before the NEB itself will assess environmental effects of a proposed export. At least at present, the NEB appears to have comfort in the assessment and regulation of both downstream LNG shipping and upstream oil and gas development in British Columbia. So long as a necessary connection exists in an export licence application, 
however, there is a risk that the NEB will conduct an assessment of that proposal's environmental effects. This increases the regulatory risk associated with that export proposal.

\section{IS MORE INNOVATION IN EXPORT LICENCE REQUIREMENTS STILL REQUIRED?}

As demonstrated in the Kitimat LNG export licence proceeding, the NEB has applied its traditional requirements for export licences flexibly to accommodate new exports of LNG from Canada. While this decision is a strong precedent for future LNG export licence applications, a fundamental question remains: should the export licence requirement be further reconsidered in light of current market dynamics?

The last time that the NEB conducted an inquiry into the appropriateness of the MBP was 20 years ago. Since that time, the natural gas market in North America has been completely transformed. Natural gas produced in the US is displacing Canadian natural gas in its traditional markets, both in Canada and the US. In order for natural gas from the Western Canadian Sedimentary Basin to continue to be produced at historic levels, let alone increased to target new shale gas plays in northeast British Columbia and the vast gas fields of the Mackenzie Valley, producers need access to new markets that can attract prices and returns that will allow for the continued investment and development of Canadian natural gas supply resources. ${ }^{92}$

The NEB explicitly recognized these changing market dynamics for natural gas in its GH1-2011 Decision by stating that:

\footnotetext{
Since deregulation in 1985, North American gas markets have functioned efficiently and there is no evidence to suggest that they will not continue to do so in the future.... The Board is of the view that should development of specific sources of supply not materialize over the proposed licence term, the Board is confident that market prices will adjust and will provide the appropriate incentive to accelerate development of other existing or alternative supplies. ${ }^{93}$
}

Therefore, the dynamic nature of the market, combined with new large supply sources, means that the North American market can now accommodate significant volumes of natural gas exports without affecting the ability of consumers to meet their needs at fair market prices. In addition, the fact that natural gas produced in the US is increasingly entering markets in central Canada erodes the original premise of requiring export licence authorizations for natural gas, which is that "Canada is dependent on its own resources for its supply of gas." 94

KM LNG Response, supra note 66 at 10-11.

GH-1-2011 Decision, supra note 72 at 19. Further, in the BC LNG Export Co-operative proceeding, the NEB stated: "The Board notes the demonstrated ability of the North American natural gas market to accommodate significant changes in supply, demand and prices.... The dynamic and evolving nature of the North American natural gas market suggests that supplies are brought forward as required with prices adjusting to provide appropriate incentives for consumers and producers" (GH-003-2011 Decision, supra note 85 at 15).

Borden Report, supra note 55 at 10. 
Since deregulation in 1985, the NEB has not sought to protect consumers from price increases and has instead focused on the ability of the market to function properly. While the "market" in this context has historically been limited to the Canadian or the North American natural gas market, global LNG trade now allows Canada to participate in a global natural gas market that allows for greater returns on Canadian resources (which are ultimately owned by the Canadian public) and also provides access to global natural gas supplies with which to meet Canadian demands. In this new global context, it seems highly unlikely that Canadian consumers will be unable to secure sufficient gas supplies for their needs at fair market prices.

Throughout Canada's history, the nation has capitalized on exporting natural resources to the rest of the world, from fur pelts to lumber, coal, precious metals, and uranium. None of these natural resources require an export authorization similar to the requirement for natural gas in the NEB Act. ${ }^{95}$ Given the change in market dynamics for natural gas and the fact that Canadians are no longer dependent on Canadian natural gas to meet their energy needs, is it in the national interest to treat natural gas any differently from these other resources?

Removing the requirement for an export licence for natural gas would require amendments to the NEB Act and would represent a dramatic narrowing in the powers of the NEB to regulate energy trade in Canada. However, so long as section 118 of the Act requires that all natural gas exports be surplus to domestic needs, the NEB will be required to retain some level of oversight over natural gas exports. In the absence of regulatory reform, the fundamental question should be whether the MBP as it is currently applied is appropriate in today's market environment for exports of LNG from Canada. The NEB's recent export licence decisions suggest that no proposed LNG export in the foreseeable future will cause Canadians any difficulty in meeting their energy needs at fair market prices, and that Canadian consumers would have no interest in contracting for natural gas on similar terms as an LNG export to Asia. In addition, the "Other Public Interest Considerations" of the MBP, such as adequacy of supply, transportation, and markets have been modified by the NEB to such an extent that in the BC LNG Export Co-operative proceeding it approved BC LNG's application absent evidence of firm supply, transportation, or markets for the duration of the export. ${ }^{96}$

Therefore, perhaps it is time for the NEB to hold a new inquiry on the MBP, one that reconsiders whether proponents should be expected to meet all of its historic requirements in the context of LNG exports. The need for a necessary connection test, for example, should be reconsidered in light of the fact that export licences are merely economic authorizations and that any physical activities associated with an export proposal, including construction and operation of the export terminal, downstream shipping, and upstream development, are all already subject to comprehensive environmental assessment and regulatory regimes. The

95 We note that export permits are required from Foreign Affairs and International Trade Canada for uranium pursuant to the Export Control List, SOR/89-202, which is designed to ensure that the destination for the export is not a country included in the "Area List" (that is, countries that are deemed necessary to control exports to). These permit applications are processed in ten days to eight weeks depending on the destination country for the goods. 
NEB itself should be able to satisfy the surplus test in section 118 of the NEB Act simply through regular monitoring of the natural gas markets to ensure that markets are functioning properly. Proponents would then be responsible for providing the NEB with any information deemed necessary to determine whether the export proposal is in the public interest, but the export licence application itself would be greatly simplified and licences could be obtained much more quickly and without the need for oral hearings. Such change would allow the NEB to retain oversight of the natural gas markets to ensure that Canadian domestic requirements continue to be satisfied, but it would simultaneously enhance the ability of Canadian resources to access new and vital markets. In our view, such a change would clearly be in the national public interest.

\section{MARKeTING ARRANGEMENTS AND ROLE OF LNG BUyerS}

Without security of long-term LNG sales contracts that provide the return on investment to justify the extraordinary commitment of the time, capital, and resources required to secure approval for, and construction of, pipelines and LNG facilities, none of the foregoing matters. Efforts need to be expended early to develop a solid understanding of the global LNG marketplace to help address and counter any threats from competing LNG projects, identify interested LNG buyers, and to build the relationships required by the potential LNG buyers before they are comfortable making the long-term commitment to an LNG project. Efforts to meet regularly with such buyers on their soil helps establish the long-term relationship being evaluated.

Determining a minimum percentage of firm capacity commitments and the duration over which such commitments are required from LNG buyers before a seller is comfortable proceeding with a final investment decision to construct requires a good understanding of overall project costs and depends in part on a party's risk tolerance. Understanding overall project costs when front-end engineering and design is not complete, the size of the pipeline or number of liquefaction trains continues to evolve, or the number of shippers or owners is in flux, requires tremendous up-front contingency planning, reserve analysis, gas market grid analysis, and flexible thinking in terms of cost per tonne of loaded LNG before negotiations over price can occur.

LNG buyers who enter into long-term contracts are concerned with security of supply and ensuring that their counterparties will be able to meet such long-term commitments. As a result, they take a keen interest in understanding every aspect of a potential LNG project, including upstream development plans. Many such LNG buyers seek to acquire not only the LNG offtake, but also an equity interest in the LNG project through to the rock face to understand the dynamics of the project. For a project developer, this means that pre-FID risk reduction and mitigation is necessarily critical not only for the owners' shareholders, but is ultimately fundamental to the LNG marketing effort and the viability of the project itself.

\section{Managing Risks Across the Project Prior TO MAKING A FINAL INVESTMENT DECISION}

The process of preparing to make a final investment decision in an LNG project takes a considerable and consistent commitment over a period of two to three years, not months. A 
critical component to identifying risks, evaluating their impact on timing and cost, and jointly resolving issues that could delay a project requires the regular exchange of information and ideas at every level and regular reporting to a management committee with oversight over the whole project who similarly meet regularly to provide feedback, direction, and advice. Finding credit-worthy, like-minded partners who have complementary strengths and relationships that bolster the project but respect the role of the operator is also important to offsetting capital risk.

Early and continued engagement with federal, provincial, and local governments, regulators, communities, and First Nations is imperative to identifying and managing potential risks to the project. If a project is to be located on Aboriginal lands, securing the support of the affected First Nations groups under an IBA or otherwise prior to conducting the required environmental assessments and prior to any regulatory hearing is critical to achieving timely regulatory project approvals. It is also a critical first step before proceeding with other commercial commitments, as without their support, such projects will not succeed. Understanding the risks associated with whatever regulatory jurisdiction and authority governs the project and proactively managing the process to mitigate against a vacuum of authority is also important to keeping the project on track.

There are a number of approaches to managing risk prior to making a substantial investment in an energy project. From an organizational perspective, having a project manager or engineer map out the proposed location and scope of the project, all the interested players, regulatory jurisdictional issues and authorities, internal resources, and end users that are critical to a decision to proceed is the first step. As a project of this nature proceeds down many simultaneous paths at varying rates, multidisciplinary teams led by key management personnel are required for simultaneously directing LNG marketing activities, terminal ownership and operational matters, pipeline ownership and operational matters, construction matters, identifying and securing required regulatory approvals, and consultation and joint ownership matters.

From a legal perspective, having lawyers who can think outside the box to provide innovative solutions to problems for which precedents are not available and ensuring their involvement in both strategic and drafting discussions is imperative in successfully managing the many disparate pieces into an integrated project in a consistent and cost effective manner. 